\title{
Pituitary Necrosis in a Case of Diabetes Mellitus
}

\section{S. KIJIMA, Y. KITAURA and T. IGARASHI}

(Department of Internal Medicine, Kobe Municipal Central Hospital, Japan)

A case is reported of a 42-year-old woman dying of complicated diabetes mellitus. In an attempt to study the pathological changes in the anterior lobe of the hypophysis on serial section, two areas of necrosis were found, in which one was round and the other was wedge-shaped. The former was $1.0 \mathrm{~mm}$. in diameter and the other was $1.5 \mathrm{~mm}$. in length. It is conceivable that these are too small to exert any effect on the pituitary function. While the cause is unknown there is good reason to suspect that the necrosis is of ischemic origin in relation to arteriosclerosis.

(pp. 983 987) 


\section{下垂体前葉壊死をおこした糖尿病の 1 例}

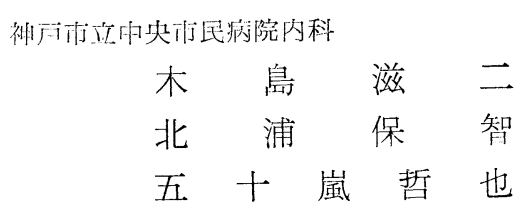

(炤和38年 6 月 19 日受付)

糖尿病屍に，下垂体前葉壊死をみるととは，少なくないという人もあるのに，わが国では，ほとんどその 報告がない, 私たちは, 生前通常の糖尿病と考朰られた1例につき, 解剖の結果, たまたま, 下垂体前葉壊 死を発見し，その病理学的変化を詳細に調べる機会に恵まれたので報告する。

症例

患者: 北○圱 $\bigcirc 42$ 才, 女 家婦

主訴 : 多飲, 多尿, やせ, 味, 嗅, 視覚および聴力障害

既往歴 : 特別のことはない.

現病歴：昭和35年 7 月下旬から，のどの渴き，多飲，多尿が現われ，甘い物がむやみに欲しくなり，また， 陰唇部がはれて，かゆくなつたりした。糖尿病と診断されて，食䬣を制限していたが，次第にやせ始め，浮 腫出没，体力が衰えて，12月には，歩行困難となった，そのころ，かぜをひいて，喘息様のせきとたん，胸 痛があり, 病臥するようになつたが, 衰弱がますます加わり, 昭和 36 年 1 月から, 糖尿病内服薬の投与を受 けているが, 効果が現われない。 2 月からは，味覚，嗅覚がなくなり，視力も低下し，難聴も党えるように なつたので, 昭和 36 年 4 月14日入院した。 月経は，15 時初潮以来順調であつたが，発病以来止まつている.

入院時所見 : 体格中等, 栄養衰え, 皮膚やや荅白, むく久気味で, 顔つきは, Fig.1 の如く, 眼球軽度突

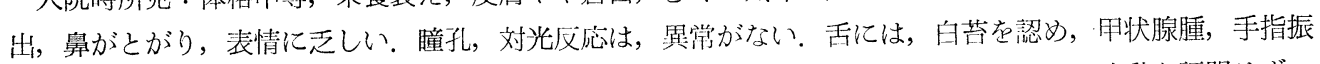
顫は認められない，脈拍87, 整, 胸部に特別の变化は見られない, 腹部膨満しているが, 波動老証明せず, 肝, 脾を触れない, 下肢は, 浮腫著明, 膝蓋腱およびアヒレス腱反射が消失しているが, 知覚異常は認めら れない.

検查所見：血圧 $115 / 75$, 尿蛋白 (一), 糖 (H+ ), ウロビリノーゲン (-), アセトン (-), 沈渣に, 赤血球,

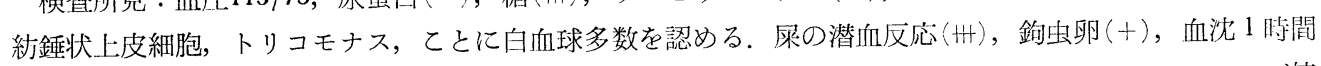
值 50 ミリ， 2 時間值 95 ミ。，血液化学検査では，血清蛋白量 $5.1 \mathrm{~g} / \mathrm{dl}, \mathrm{A} / \mathrm{G}$ 比 0.50, コリンエステラーゼ値 $(\mathrm{pHH}) 0.2, \mathrm{CGF}($-)，アルカリホスファターゼ4.2U，総コレステロール值 $230 \mathrm{mg} / \mathrm{dl}$, アミラーゼ $72 \mathrm{U}$, $\mathrm{Na} 135 \mathrm{mEq} / 1, \mathrm{~K} 4.7 \mathrm{mEq} / 1$. 血液所見は，赤血球数 180 万，血色素量 $6.3 \mathrm{~g} / \mathrm{dl} ，$ ヘマトクリット值 $18 \%$, 白 血球数 16,500 , 百分比では好中球 $70 \%$ (桿核球 $11 \%$ ，分節核球 $59 \%$ ），好酸球 $1 \%$ ，好塩基球 $1 \%$ ，リンパ 球28\%。たん結核菌とまつ(一)，胸部X線所見，心電図には著変を認めない。トルコ鞍X線撮影では異常は 涊められない。

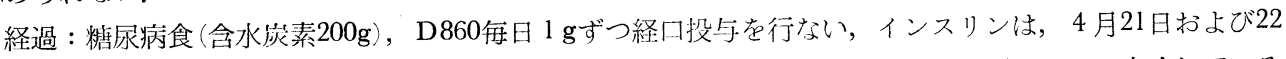
日の 2 日間20単位ずつ使用したが，急速に食思不振，沈衰，もうろう状態を示すに至つたので中止している。 尿量は 1 日量4,000ccから $2,000 \mathrm{cc}$ に減少したが，1 日の排糖量は10６00 と一定しない．4月20日頃から， 残尿多く，下腹部膨隆し，導尿で排尿していたが，4月28日から発熱 $38^{\circ} \mathrm{C}$ 前後を来たし，シノミン，クロマ イ投与により下熱したが，衰弱加わり，喍眠状となり 5 月 8 日死亡した，在院日数 29 日，全経過 9 ケ月余で

$$
\text { 第39卷 第10号 }
$$


Fig. 1. Emaciation and facial expression at the time of the admission into the hospital

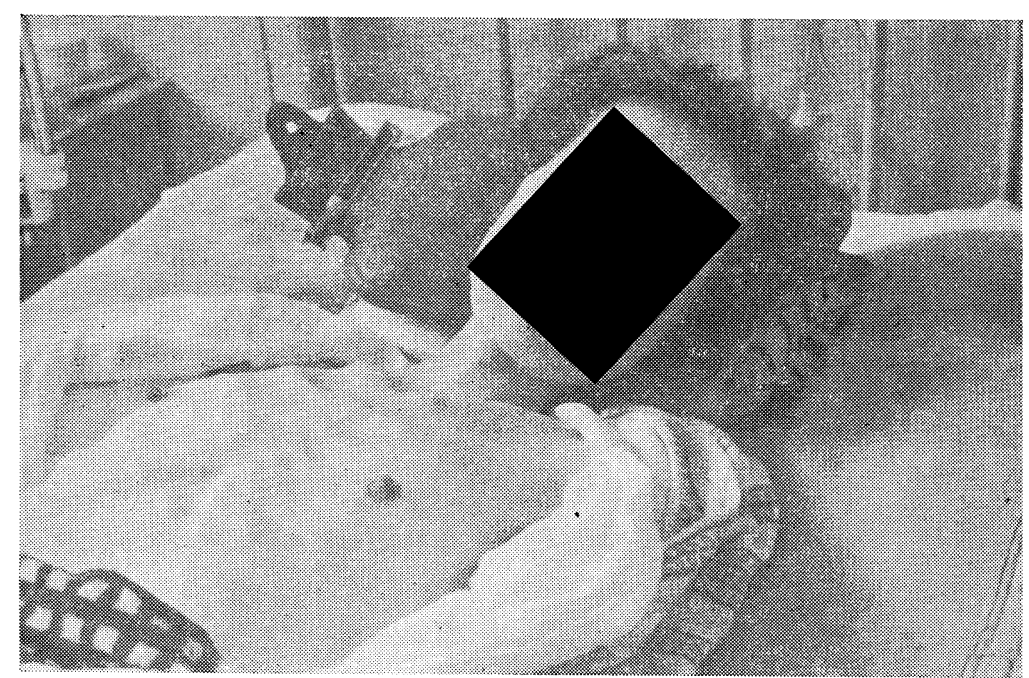

ある.

5 月 6 日の検査では，尿アセトン $(-)$, 血液所見では，赤血球数 57 万，血色素量 $2.4 \mathrm{~g} / \mathrm{d} 1$, 、マトクリッ 卜值 $7 \%$, 白血球数 13,800 , 好中球 $71 \%$ （桿核球 $13 \%$, 分節核球 $58 \%$ ，好酸球 $0 \%$, 好塩基球 $0 \%$ ，単球 $1 \%$, リンパ球 $28 \%$ である. 血液化学検査では, 血清蛋白量 $6.0 \mathrm{~g} / \mathrm{d} 1, \mathrm{~A} / \mathrm{G}$ 比 0.2 , コリンエステラーゼ值 0.2, CGF (一), 総コレステロール值 $204 \mathrm{mg} / \mathrm{dl}, \mathrm{GOT} 6 \mathrm{U}$, 尿素 N $64.2 \mathrm{mg} / \mathrm{dl}, \mathrm{GRP}$ (卅). 髄液所見は, 無色透明, 初圧 $130 \mathrm{mmH}_{-} \mathrm{O}, 1 \mathrm{cc}$ 採取して, 終圧 $110 \mathrm{~mm} \mathrm{H}_{-} \mathrm{O}$, 細胞数 $3 / 3$, ノンネアペルト (一), 蛋白量 $36 \mathrm{mg} / \mathrm{dl}$ である.

Fig. 2. Parenchymatous cells are atrophic and dissociated from the sinusoid capillary.

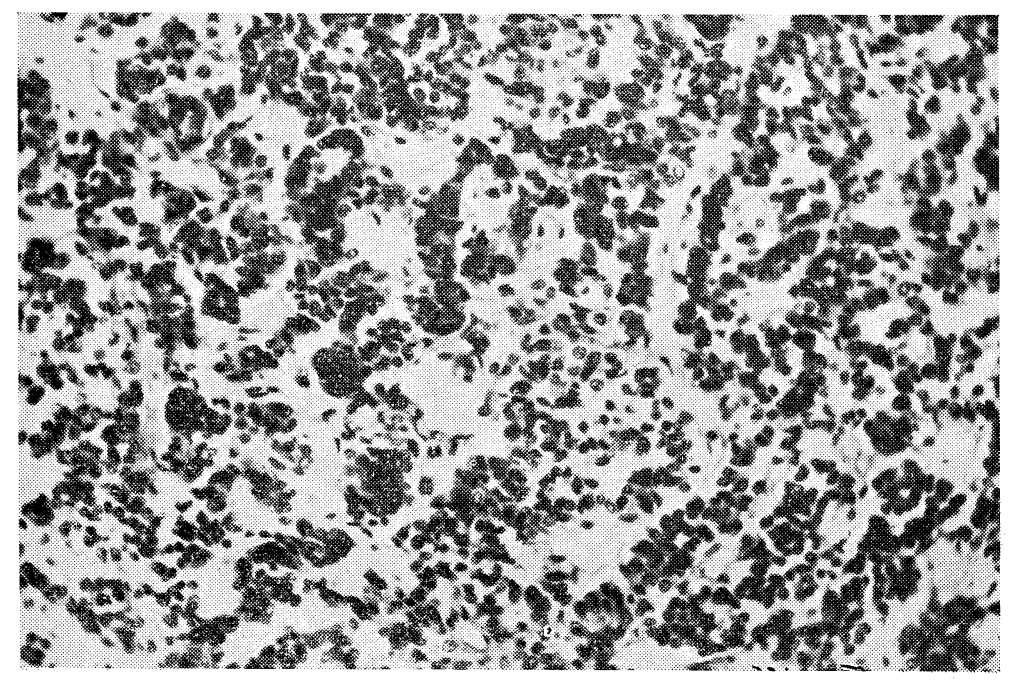


剖検所見 : 解剖所見は, 糖尿病, すなわち膵臟島減少および島細胞変性, 合併症として左肺膿焬, 両側化 膿性気管支炎，両側乙とに右の膿腎，腎㙉腎炎，化膿性膀胱炎，尿管拡張，尿道狭窄などか認められる.

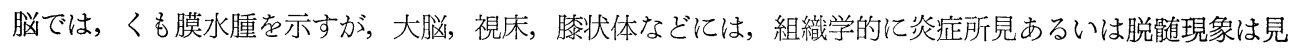
られない，とてろが，嗅，視神経など脳神経では，グリヤ細胞の增殖，ビルショウスキイ染色でも，線維の 蛇行, 断裂が認められ，多発性神経炎の像と考光られる所見を示している.

さて，下垂体前葉では洞毛細血管と実質細胞の間除が解離を示し，実質細胞は菱縮状で，乙とに $\boldsymbol{\alpha}$ 細胞は 周辺部においてもその数が少なく，かつ菱縮している Fig. 2. また前葉には，連続切片により観察すると， 2 コの凝固壊死巣が認められ，その一つは側方結合織血管索を頂点とする楔形をなし，長形 $1.5 \mathrm{~mm} ，$ 他の 一つは円形で，直径は $1 \mathrm{~mm}$ ，两側性と思われるFig.3. 壞死巣周囲には，細胞反応は認められないFig.4.

Fig. 3. Two areas of necrosis are found in which the left is wedge-shaped and the right is round.

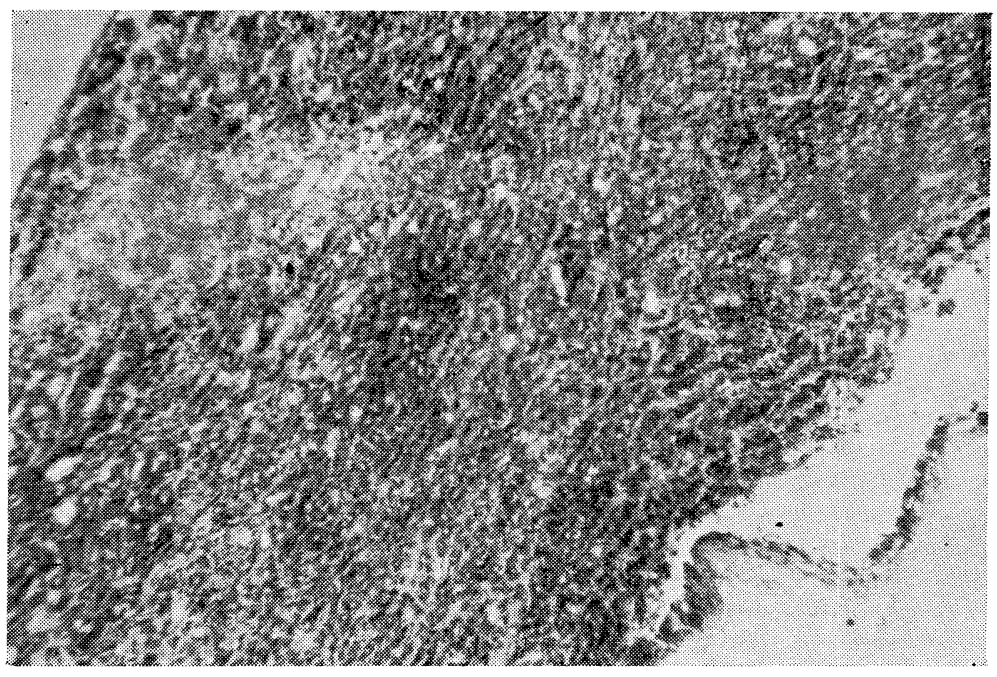

Fig. 4. No cell reactions are found around the necrotic area.

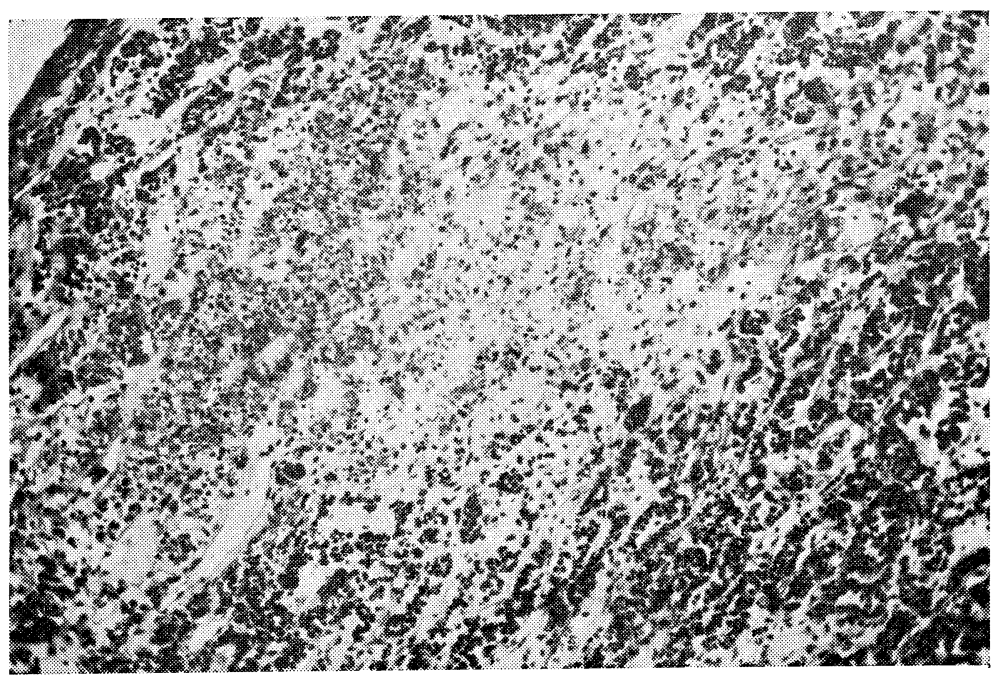

第39巻 第10号 
4 図)。また，病栄内および周辺においては，拡㖘した洞内に白血球が認められ，血管外にも，核破片の散 在を恋める。側方結合織血管索における血管壁にはとくに異常を吠めない.

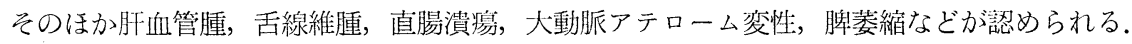

\section{考按}

ての症例は 42 才の女子で，生前通常の糖尿病として扱われたが，合併した感染症，てとに尿路系の化膿性 炎が，有力な死因となつたと考えられる患者である。しかし，解剖の結果たまたま生前誩断し得なかつた下 垂体前葉瀤死を発見したものである。

諸種疾患につき，病理解剖学的に下垂体前葉壊死を観察したものには，1920年 $\mathrm{Kraus}^{1)}$ 以来， Balo²)，Ki-

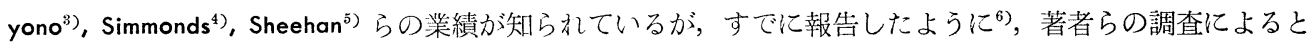
1940年までに諸家文献例95例，自験例24例，合せて119例である。病名別では産褯期に最も多く出現し，そ のほか敗血症，流行性出血熱，糖㽷病，化膿性髅膜炎などに認められることが多い，さて，その後下垂体壊 死に関する研究は，約10年間のほとんど空白な期間を経て，1950年代に入り，ふたたび脚光を浴びたかのよ

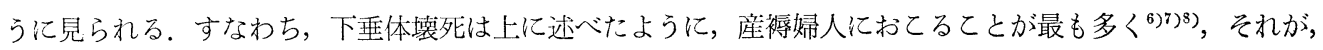
Sheehan 症候群や Simmonds 症候群の原因ともなるのであるが，直径 $2 \mathrm{~mm}$ 以下程度の小範冉の壊死は， Plaut ${ }^{9}$ の報告仁も市るとおり, 決してまれなものではなく, 連続切片を作つて調べると通常の剖検でも, 大 約 $3 \%$ 程度に認められるという文。

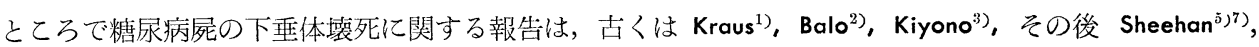

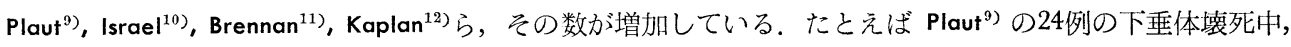
糖尿病は 2 例であり，Brennan ${ }^{11}$ によると，成人7326屍体中，糖尿病患者は146例で，その中 3 例に下垂体壊 死か認められ，非糖尿病患者7180例中13例に壊死を認めている．すなわち糖尿病の場合には，他の一般の疾 病の場合の約10倍の頻度で，下垂体壊死が発見されると述べている。

糖尿病屍の下垂体前葉各細胞の示す態度につき，Kraus ${ }^{1)}, K_{i y o n o}{ }^{3)} ， C_{u n z}{ }^{13)}$ らは， $\alpha$ 細胞減少に注目し， $\mathrm{Fry}^{14)}$ は $\alpha$ 細胞の腺腫性增殖を記載し，またそれを後述のように，糖尿病の発生機序に結びつけて，下垂体 前葉成長ホルモンとの関係を考学るならば， $\alpha$ 細胞减少よりもむしろ増加が認められて然るべきと述へてい る人もある ${ }^{15}$. $\beta$ 細胞， $\gamma$ 細胞についても若干の報告がなされている ${ }^{13) 16(1) 17)}$. 要するに糖㽷病の場合, 前 葉細胞の態度については諸説があつて一致しない，それはその場合の糖尿病に色々の異なつた成因のものが 含まれているためであろう，私たちの症例については $\alpha$ 細胞の著しい減少のほか， $\gamma$ 細胞にも萎縮を認めて いる.

次に下垂体何何故に壊死ができるかという問題について, 最も頻度の多い産褯婦人ではそれまで血栓, 栓 塞によるとする説が有であつたのをら゙，奏は胎盤アレルギー性血管スパスムスによる貧血性梗塞と解すべき であるというととを著者らがすでに昭和 23 年の日本内分泌学会で報告している ${ }^{6}$ ．ところが産褯婦人の下垂 体壊死について最も多くの症例をもつSheehan が，当時は子宮出血にもとづく乏血を成因と唱えていたの 亿最近は血管スパスムス説に傾いているようである7).

糖永病の場合についても壊死の形態は, 周囲に細胞反応を伴わない分血性梗塞であるから, 当然血行性障 㕩を考えなければならないが，産褯婦人の場合のようにアレルギー性要素を想定するてとは困難であるから， 動脈硬化と関係のあるき血に帰すべきものかと思われる。

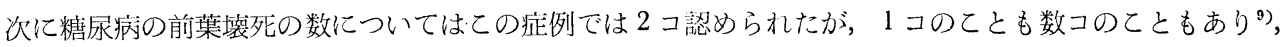
2 コ以上のものは左右刘称的に分れているてとが多いようであるが占，ての症例もそれに近いものである.

壞死の大きさは Plaut $\left.{ }^{9}\right)$ の報告では, $1 \mathrm{~mm} \sim 5 \mathrm{~mm}$ まであり, その中本症例のように, $2 \mathrm{~mm}$ 以下とい う小さなものが13例中10例を占めており，また Sheehan and Summer ${ }^{18)}$ は，前葉破壊の大いさにより， severe, moderate, minor, slight の四段階に分けているが，ての症例はslight，すなわち1/4あるいはそれ より少ない破壊に属している，壊死の形は貧血性梗塞に似ているといつても，必ずしも楔形とは限らず， 
Plaut ${ }^{9)}$ も楔形のものは一つもないと述べている．私たちの症例は 2 コの中 1 コは円形を示したが，他の1コ は楔形に近い像を示しており，血栓てそ証明できないが原因が動脈にあるてとを物語つている.

次に壊死により下垂体の機能が廃絶すれば，糖尿病の臨床経過にどのような影響を及ぼすかということは， 実験的に下垂体を剔出するてとのできない人体については極めて興味のある課題である．すなわち，荟摘出 犬で下垂体を剔出すると, 糖尿病は軽快し, 下垂体前葉移植によりふたたび悪化するという Houssay (1930) ${ }^{19)}$ の実験は，あまりにも有名であるが，てれにより膵剔出糖尿病に下垂体が関与するてとが初めて明らかとな つている. 一方ての Houssay 現象の人間版ともいうべきものとして ${ }^{20)}$, 糖尿病が下垂体機能低下を来たす ことにより好転する事実か知られて来ている ${ }^{21}$ ．従来糖尿病と下垂体機能低下が併存するてとはまれである といわれているが(10)11112)222)，最近では漸次その数が増えているようである。その場合，糖尿病は一時好転を 示すのがふつうであるが，一方患者がインスリン療法を必要としてもインスリンに対し感受性がたかまり， 低血糖症状から回復し得ない状態をひきおてすてとが，しばしばのようである ${ }^{12}$. その発生機転につき，肝 の低血糖調節機序消失, 血液あるいは組織によるインスリン不活性化の程度を減ずるため, 前葉とくに成長 ホルモンの抗インスリン因子の欠如のためなどの説明がなされている ${ }^{23}$. ての症例は臨床的にはるいそうが 著しく，Isaael, Baennan, Kaplan, Grunberg ら下垂体の機能低下を思わせる所見も示している。 てれは， 病理組織学的に $\alpha$ 細胞の減少しているととと関係があるとは思われるが，壊死にもとづく下垂体前葉の機能 廃絶に帰するのはあたらない. Israel ${ }^{10)}$ は, 下垂体の残存健常実質が10〜15\%あ机ば臨床上問題となるほど の症状はおてさないと述べているが, 径 $2 \mathrm{~mm}$ 程度の小さな壊死巣では腺性臓器である下垂体の全機能に対 してはとくべつの影響を及ぼさなかつたであろう，従つてての患者では糖尿病の経過に対しても，Houssay 現象というほどの影響を及ぼすてとはできなかつたものと思われる。

\section{むすび}

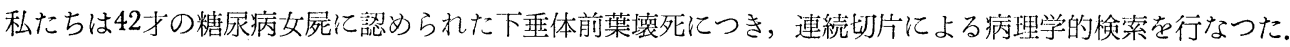
壤死の数は 2 コ認められ，その一つは归を示し，他の 1 コは楔形状を示した．壊死の大いさは円形のもの は径 $1 \mathrm{~mm}$, 楔形状のものは長径 $1.5 \mathrm{~mm}$ でいわゆる小範囲のものに属し, 下垂体機能に対しとくべつの影 響は及ぼさなかつたものと推定される，また壊死の成因については，血管性要素，すなわち動脈硬化と関係 のある乏血に䗖すべきものと考えられる.

(本論交の要旨は, 婟和 38 年 4 月日本内分泌学会の席上発表した。)

\section{主 要 文 献}

1) KRAUS, E.J. : Virchow's Arch., $228: 68$, (1920).

2) BALO, J. : Beitr. z. pathol. Anat. u. allg. Pathol., $72: 599$, (1923).

3) KIYONO, H. : Virohow's Arch., $262: 149$, (1926). SIMMONDS, J.P. : Endocrinology, $9: 117$, (1925).

5) SHEEHAN, H.L. : J. Path. \& Bact., 45 : 189, (1937). 6) 木島滋二 : 日新医学, 36(2), 47 (昭24). 7) SHEEHAN, H.L. and STANFIELD, J.P. : Acta Endocrinol., 37 : 509, (1961)。 8) 木島滋二 : 日本内分泌学会雑誌, 24, 18 (昭 23). 9) PLAUT, A. : Am. J. Pathol., $28: 883$ (1952). 10) ISRAEL, S.L. and CONSTON, A.S. : J.A.M.A., $148: 189$ (1952). 11) BRENNAN, C.F., MALONE, R.G.S. \& WEAVER, J.A. : Lancet, No. $6932: 12$, (1956).

12) KAPLAN, N.M., PARKER, G.W. \& BEERING, S.G. : Metabolism, $10: 447$, (1961). 13) GUNZ, H. : Schweiz. Med. Wschr., 75 : 561, (1945). FRY, H.B. : Quart. J. Med., $8: 277$, (1915).

15) 斉藤達雄: 現代内科学大系, 代謝異常 II, 中山 書店, p. $68(1960)$. 16) GROOKE, A.C. : J. Path. \& Bact., $41: 339$, (1935).

HAWKING, F. : J. Path. \& Bact., $42: 689$, (1936).

18) SHEEHAN, H.L. \& SUMMER, V.K. : Quart. J. Med., 18 : 319, (1949). 19) HOUSSAY, B.A. \& BIASOTTI, A. : Arch. f. Ges. Physiol., 227 : 664, (1931). 20) CALVERT, R.J. and CAPLIN, G. : Brit. Med. J., $2: 71$, (1957). 21) GEORAS, G.S., MEISSNER, G.F., DILTON, J.A. and GALENDA, D.G. : New Eng. J. Med., 263 : 374, (1960). 22) GRUNBERG, A. and BLAIR, J.L. : Brit. Med. J., 2 : 439, (1957). 23) 中尾・中村・大森：脳下垂体ホルモン，生理と薬理，医学書院 (1957). 